\title{
Ekonomi Kreatif: Pemanfaatan Limbah Jelantah Untuk Pembuatan Lilin Aromaterapi
}

\author{
Dyah Titis Kusuma Wardani', Endah Saptutyningsih², dan Suci Alpika Fitri3 \\ ${ }^{1,2}$ Program Studi Ekonomi, Fakultas Ekonomi dan Bisnis, Universitas Muhammadiyah Yogyakarta \\ ${ }^{3}$ International Program for Islamic Economics and Finance, Universitas Muhammadiyah Yogyakarta \\ E-mail: dyah.wardani@umy.ac.id \\ DOI: $10.18196 / p p m .32 .224$
}

\begin{abstract}
Abstrak
Permasalahan yang ditemukan di Dusun Sorowajan, Pedukuhan Glugo, Desa Pangungharjo, Kecamatan Sewon, Kabupaten Bantul adalah adanya potensi limbah rumah tangga desa yang belum dimanfaatkan dengan baik. Hal ini disebabkan kurangnya keterampilan dalam mengelola potensi bahan alami dan limbah rumah tangga desa. Program Kemitraan Masyarakat ini bertujuan untuk memberikan solusi dengan memanfaatkan potensi bahan alami yaitu sereh, daun jeruk nipis, dan limbah rumah tangga yang dimiliki desa yaitu minyak jelantah sisa penggorengan. Selain itu, program ini juga bertujuan meningkatkan kemampuan warga dalam menciptakan ekonomi kreatif dengan memanfaatkan potensi alam di desanya. Kegiatan pengabdian yang dilakukan tim PKM UMY di Dusun Sorowojan menggunakan beberapa pendekatan, yaitu: (1) berbasis kelompok, (2) bersifat komprehensif, dan (3) berbasis pemanfaatan potensi alam lokal. Kegiatan ini menggunakan tiga metode, yaitu (1) metode partisipasi, yaitu tim pengabdian melakukan partisipasi aktif serta melakukan pemberdayaan masyarakat dalam pelatihan pembuatan lilin aromaterapi; (2) metode survei, yaitu menyebarkan kuesioner kepada peserta pelatihan sebelum pelaksanaan dan sesudah pelaksanaan, serta survei kepuasan mitra pengabdian dan (3) metode audio-visual, yaitu memanfaatkan video sebagai sarana pelatihan dan sosialisasi kegiatan. Program Kemitraan Masyarakat ini diawali dengan mengadakan pelatihan pembuatan lilin aromaterapi dengan memanfaatkan minyak jelantah yang ada di lingkungan Dusun Sorowajan. Kegiatan ini memberikan manfaat langsung terhadap kehidupan masyarakat di bidang sosial dan ekonomi melalui ekonomi kreatif. Selain itu, kegiatan ini juga meningkatkan kualitas sumber daya masyarakat melalui pemberdayaan ibu-ibu kelompok Dasawisma Lili di Dusun Sorowajan, Desa Panggungharjo. Pelatihan ini membuahkan hasil, yakni mampu meningkatkan keterampilan ibu-ibu di Kelompok Dasawisma Lili Dusun Sorowajan dalam membuat produk lilin aromaterapi. Video tutorial teknik pembuatan lilin aromaterapi yang telah dibuat bisa dinikmati masyarakat umum. Pelatihan ini juga telah meningkatkan keterampilan kelompok Dasawisma tersebut dalam memasarkan produk lilin aromaterapi secara online. Kegiatan Program Kemitraan Masyarakat ini telah disosialisasikan di media massa dan akan dipublikasikan di jurnal nasional. Dengan demikian kegiatan ini diharapkan dapat menjadi acuan bagi kelompok masyarakat lain untuk meningkatkan kapasitas masyarakat dalam memanfaatkan potensi desa yang ada dan meningkatkan kesejahteraan masyarakat melalui ekonomi kreatif.
\end{abstract}

Kata Kunci: Lilin aromaterapi, Limbah, Ekonomi kreatif, Pemberdayaan masyarakat, Pemasaran online

\section{Pendahuluan}

Program Kemitraan Masyarakat Universitas Muhammadiyah Yogyakarta merupakan program pemberdayaan masyarakat dengan tujuan meningkatkan potensi, baik itu kualitas sumber daya manusia maupun potensi alam yang ada di sekitar masyarakat, untuk dapat diolah agar memiliki nilai guna lebih dari yang sudah ada. Di Dusun Sorowajan, Pedukuhan Glugo, Desa Pangungharjo, Kecamatan Sewon, hal tersebut belum terlaksana dengan baik. Untuk itu, masih dibutuhkan usaha pengembangan dan pengorganisasian yang lebih baik lagi. Misalnya, di bidang keterampilan, hasil karya ibu-ibu Dasawisma masih membutuhkan pelatihan lebih lanjut dalam mengelola potensi alam desa. Mayoritas ibu-ibu Dasawisma di Dusun Sorowojan adalah ibu rumah tangga yang tidak memiliki keterampilan sehingga memerlukan pendampingan dan pelatihan dalam meningkatkan penghasilan keluarga agar ekonomi keluarga tidak tergantung sepenuhnya pada penghasilan kepala keluarga.

Permasalahan yang ditemukan di Dusun Sorowajan adalah 1) masyarakat Dasawisma ini didominasi ibu rumah tangga yangbelum memanfaatkan potensi alami desa dengan baik, 2) kurangnya keterampilan dalam mengelola potensi desa, dan 3) minimnya penghasilan karena mayoritas penduduk Dusun Sorowajan adalah ibu rumah tangga. Adanya pelatihan lilin aromatarapi dengan memafaatkan bahan alami yang ada di lingkungan Dusun Sorowajan, seperti daun jeruk, sereh, dan limbah rumah tangga dapat memberikan manfaat secara langsung terhadap kehidupan masyarakat di bidang sosial dan ekonomi. Selain itu, pelatihan ini juga 
meningkatkan kualitas sumber daya manusia melalui pemberdayaan ibu-ibu Dasawisma Dusun Sorowajan.

Segala sesuatu bisa dinilai dengan uang. Di zaman yang semakin menjamurnya kreativitas dan apresiasi masyarakat, banyak sumber daya alam yang bisa diolah atau didaur ulang oleh masyarakat. Selain bermanfaat untuk diri sendiri, daur ulang sumber daya alam ini juga dapat bermanfaat untuk orang lain, yakni bisa menjadi sumber ekonomi bagi mereka yang mau sedikit berkreativitas. Salah satu hasil kreativitas tersebut adalah lilin sebagai sumber penerangan, alternatif dekorasi ruangan, dan media aromaterapi (Murhananto and Aryasatyani, 2004).

Lilin telah digunakan secara luas sepanjang sejarah tidak hanya sebagai alat penerang, tetapi juga sebagai cara untuk mengatur suasana hati. Lilin yang dimaksud adalah lilin aromaterapi. Lilin aromaterapi adalah lilin yang mengandung bahan pewangi yang dapat digunakan sebagai refreshing, relaxing, dan penyembuhn sakit kepala. Lilin aromaterapi dapat digunakan untuk berbagai tujuan, termasuk menghilangkan stres dan kecemasan (Rizka, 2014).

Lilin aromaterapi merupakan aplikasi lain dari lilin yang sudah ada. Dalan pembuatan lilin aromaterapi menggunakan beberapa bahan. Salah satunya menggunakan minyak aroma (essestial oil) yang memiliki wangi aromaterapi. Aromaterapi sendiri memiliki sifat yang menenangkan dan memiliki aroma yang menyegarkan (Prabandi and Febriyanti, 2017). Lilin aromaterapi memberikan efek terapi bila dibakar. Formula lilin aromaterapi yang dibuat berupa parafin, stearin, odoran, pewarna minyak dryobalanops, sereh, daun jeruk nipis, dan limbah rumah tangga yang dimiliki desa, yaitu minyak jelantah sisa penggorengan. Pelatihan pembuatan lilin aromaterapi dapat meningkatkan kemampuan warga dalam menciptakan ekonomi kreatif dengan memanfaatkan potensi alam di desanya. Berbagai formula yang dibuat menghasilkan lilin yang cukup keras dan dapat menyala dengan sempurna. Lilin aromaterapi memiliki peluang yang bagus di pasaran. Cara pembuatannya mudah, bahan juga mudah diperoleh, harganya terjangkau, dan laba yang diperoleh dari usaha pembuatan lilin aromaterapi sangat tinggi. Lilin aromaterapi bisa digunakan sebagai penghias dan pengharum ruangan serta dapat dijadikan sebagai suvenir pernikahan yang cantik (Muhabirin, 2012).

Potensi lingkungan yang ada di sekitar masyarakat perlu dimanfaatkan dengan baik, misalnya dengan menjadikannya sebagai produk yang dapat diolah sehingga bernilai jual tinggi. Hal ini dapat meningkatkan pendapatan masyarakat. Identifikasi potensi sumber daya alam dan lingkungan yang ada di sekitar masyarakat perlu dilakukan dengan berbasis kearifan lokal dalam rangka menunjang program pemerintah di bidang pengelolaan sumber daya alam dan lingkungan secara baik dan berkelanjutan (Fadhil, 2007). Salah satu pemanfaatan potensi alam adalah untuk meningkatkan pendapatan masyarakat. Oleh karena itu, perlu adanya pemberdayaan kelompok-kelompok masyarakat, khususnya kelompok ibu-ibu rumah tangga Dasawisma Lili, agar dapat menambah pemasukan keluarga secara mandiri, tidak hanya tergantung pada kepala keluarganya.

Program pemberdayaan masyarakat ini bertujuan untuk mengembangkan potensi dan keterampilan sumber daya manusia ibu-ibu Dasawisma dalam memanfaatkan potensi alam desanya, yaitu libah minyak jelantah sehingga menghasilkan sesuatu yang bernilai jual tinggi serta memberikan manfaat ekonomi dan sosial bagi masyarakat di sekitarnya. Peningkatan keterampilan ibu-ibu Dasawisma dapat menumbuhkan kegiatan ekonomi lokal yang secara tidak langsung mampu meningkatkan kesejahteraan masyarakat Dusun Sorowojan. International Labour Organization (2017) menyatakan bahwa perlu mengidentifikasi peluang pekerjaan bagi masyarakat untuk meningkatkan pendapatan masyarakat dan memberikan ideide inovatif untuk usaha baru dan peluang kerja baru. 
Dari program KKN UMY sebelumnya, ditemukan bahwa dimana melimpahnya potensi limbah minyak jelantah Dusun Sorowojan cukup melimpah, tetapi keterampilan ibu-ibu untuk mengolah limbah tersebut masih rendah. Untuk meningkatkan keterampilan dan mendorong adanya kegiatan mengolah limbah minyak jelantah diselenggarakan beberapa program, yaitu 1) pelatihan lilin aromaterapi kepada enam kelompok masyarakat (Ibu-ibu Dasawisma) Dusun Sorowajan, Pedukuhan Glugo, Desa Pangungharjo, Kecamatan Sewon, Kabupaten Bantul dan 2) pembuatan video cara membuat lilin aromaterapi dan di-upload di media sosial.

\section{Metode Pelaksanaan}

Banyaknya potensi alam di Dusun Sorowajan dan masih minimnya kemampuan kelompok masyarakat dalam menghasilkan produk lilin aromaterapi yang memberi banyak manfaat bagi kesehatan dan dapat menambah pendapatan keluarga ini menjadi permasalahan tersendiri. Kegiatan Program Kemitraan Masyarakat (PKM) ini berusaha memecahkan permasalahan tersebut, yaitu dengan beberapa pendekatan sebagai berikut:

1. Berbasis kelompok, seluruh tahap dan jenis kegiatan dilakukan oleh masyarakat lokal secara berkelompok. Kelompok masyarakat digunakan sebagai media belajar dan pendampingan, perencanaan, pelaksanaan, dan monitoring kegiatan secara daring (online).

2. Komprehensif, program PKM ini mengintervensi seluruh aspek untuk melakukan pelatihan pada kelompok Ibu-ibu Dasawisma guna meningkatkan keahlian, keterampilan, dan pengetahuan (teknik membuat lilin aromaterapi). Pelatihan dilakukan secara daring. Untuk memperkuat kegiatan kelompok dilakukan pendampingan juga secara daring.

3. Berbasis pemanfaatan potensi alam lokal. Peningkatan keterampilan pembuatan lilin aromaterapi berbasis pada potensi lokal karena memanfaatkan bahan-bahan alami yang berasal dari limbah jelantah, sereh, dan daun jeruk.

Tabel 1. Jenis kegiatan, partisipasi masyarakat, luaran kegiatan, dan solusi masalah

\begin{tabular}{|c|c|c|c|c|}
\hline No & $\begin{array}{l}\text { Pengetahuan tentang } \\
\text { pemanfaatan lingkungan }\end{array}$ & $\begin{array}{r}\text { Partisipasi } \\
\text { Masyarakat }\end{array}$ & Luaran Kegiatan & Solusi Masalah \\
\hline 1. & $\begin{array}{l}\text { Pelatihan pembuatan lilin } \\
\text { aromaterapi }\end{array}$ & $\begin{array}{l}\text { - Masyarakat berhak menentukan } \\
\text { siapa yang ikut pelatihan. } \\
\text { - Masyarakat sebagai peserta } \\
\text { aktif pelatihan. } \\
\text { - Masyarakat menyediakan } \\
\text { tempat. } \\
\text { - Masyarakat memberikan } \\
\text { masukan untuk materi video } \\
\text { teknik pembuatan lilin } \\
\text { aromaterapi }\end{array}$ & $\begin{array}{l}\text { ima) orang masing-masing } \\
\text { dari kelompok ibu-ibu } \\
\text { Dasawisma dan } \\
\text { menguasai teknik } \\
\text { pembuatan lilin } \\
\text { aromaterapi }\end{array}$ & $\begin{array}{l}\quad \text { Menggunakan } \\
\text { metode daring untuk } \\
\text { mengoptimalkan hasil } \\
\text { pelatihan }\end{array}$ \\
\hline 2. & Pembuatan video & $\begin{array}{l}\text { - Masyarakat sebagai subjek dalam } \\
\text { video cara pembuatan lilin } \\
\text { aromaterapi }\end{array}$ & $\begin{array}{l}\text { Video teknik pembuatan } \\
\text { lilin aromaterapi untuk } \\
\text { menyosialisasikan teknik } \\
\text { pembuatan lilin } \\
\text { aromaterapi }\end{array}$ & $\begin{array}{l}\quad \text { Video teknik } \\
\text { pembuatan lilin } \\
\text { aromaterapi dibuat } \\
\text { oleh tenaga } \\
\text { profesional agar } \\
\text { menarik untuk } \\
\text { dipelajari oleh } \\
\text { masyarakat luas }\end{array}$ \\
\hline
\end{tabular}

Kegiatan ini menggunakan tiga metode, yaitu (1) Metode partisipasi, tim pengabdian melakukan partisipasi aktif sekaligus menghimpun partisipasi masyarakat melalui program 
pemberdayaan masyarakat dalam pelatihan pembuatan lilin aromaterapi, (2) Metode survei, yaitu menyebarkan kuesioner kepada peserta pelatihan sebelum pelaksanaan (pre-test) dan sesudah pelaksanaan (post-test), serta survei kepuasan mitra pengabdian, (3) Metode audiovisual, yaitu memanfaatkan video sebagai sarana pelatihan dan sosialisasi kegiatan.

Kuesioner dimaksudkan untuk mengetahui ketercapaian target kegiatan. Kegiatan pelatihan pembuatan lilin aroma terapi menggunakan sistem pre-test dan post-test atau tes sebelum dan sesudah kegiatan pelatihan dengan mengisi formulir menggunakan google form yang dibagikan di kelompok Whatsapp ibu-ibu Dasawisma Lili. Beberapa pertanyaan dan analisis data tersaji dalam table-tabel pada subbab hasil dan pembahasan.

\section{Hasil dan Pembahasan}

Pelatihan lilin aromaterapi diikuti sebanyak tiga puluh peserta yang berasal dari kelompok ibu ibu Dasawisma Dusun Sorowojan. Namun, hanya ada 15 peserta yang mengisi kuesioner.

\begin{tabular}{lcc}
\multicolumn{2}{c}{ Tabel 2.1 Komposisi peserta berdasarkan jenis kelamin } \\
\hline \hline Jenis Kelamin & Jumlah & Persentase \\
\hline Laki-laki & 0 & 0 \\
Perempuan & 15 & 100 \\
\hline
\end{tabular}

Berdasarkan jenis kelamin, seluruh peserta pelatihan lilin aromaterapi berjenis kelamin perempuan.

Tabel 2.2 Komposisi peserta berdasarkan status perkawinan

\begin{tabular}{lcc}
\hline \hline Status Perkawinan & Jumlah & Persentase \\
\hline Menikah & 13 & 86,66 \\
Belum Menikah & 2 & 13,33 \\
\hline
\end{tabular}

Masyarakat peserta pelatihan adalah ibu-ibu yang tergabung di Dasawisma Lili. Jumlah peserta yang telah menikah sebanyak $86,66 \%$, sedangkan $13,33 \%$, sisanya belum atau tidak menikah.

\begin{tabular}{lcc}
\multicolumn{2}{c}{ Tabel 2.3 Komposisi peserta berdasarkan tingkat pendidikan } \\
\hline \hline Tingkat Pendidikan & Jumlah & Persentase \\
\hline SD & 2 & 13,33 \\
SMP & - & - \\
SMA & 7 & 46,66 \\
S1/Sederajat & 6 & 40,00 \\
\hline
\end{tabular}

Berdasarkan tingkat pendidikan, sebanyak 46,66 \% dari seluruh peserta lberpendidikan Sekolah Menengah Atas (SMA), $40 \%$ peserta berpendidikan strata satu (S-1), dan hanya sebanyak 13,33\% saja yang berpendidikan Sekolah Dasar (SD). 


\begin{tabular}{|c|c|c|}
\hline $\begin{array}{l}\text { Jenis ketrampilan/ } \\
\text { keahlian tertentu }\end{array}$ & Jumlah & Persentase \\
\hline Memiliki ketrampilan & 10 & 66,66 \\
\hline Tidak memiliki & 5 & 33,33 \\
\hline
\end{tabular}

Terdapat sebanyak 66,66 persen dari seluruh peserta pelatihan lilin aromaterapi tidak memiliki bekal keterampilan tertentu. Sementara 33,33 persen peserta memiliki ketrampilan tertentu, di antaranya keterampilan menjahit, ecoprint, berdagang, tekstil, dan membuat makanan.

\begin{tabular}{lcc}
\multicolumn{3}{l}{ Tabel 2.5 Komposisi peserta berdasarkan keterlibatan dengan pelatihan tertentu } \\
\hline \hline Keterlibatan & Jumlah & Persentase \\
\hline $\begin{array}{l}\text { Pernah mengikuti pelatihan } \\
\text { Tertentu }\end{array}$ & 10 & 66,66 \\
Tidak pernah & 5 & 33,33 \\
\hline
\end{tabular}

Berdasarkan keterlibatan dengan pelatihan tertentu, terdapat 66,66 persen dari seluruh peserta pernah mengikuti pelatihan tertentu, sedangkan 33,33 persen sisanya tidak pernah mengikuti pelatihan tertentu.

Tabel 2.6 Komposisi peserta berdasarkan keterlibatan dengan usaha

\begin{tabular}{ccccc}
\hline $\begin{array}{c}\text { Keterlibatan dengan } \\
\text { Usaha }\end{array}$ & Ya & Persentase & Tidak & Persentase \\
\hline Usaha Formal & 2 & 13,33 & 13 & 86,66 \\
Usaha Informal & 4 & 26,66 & 11 & 73,33 \\
Tidak terlibat & 9 & 60,00 & 6 & 40,00 \\
\hline
\end{tabular}

Seluruh peserta pelatihan lilin aromaterapi, sebanyak 60,00 persen peserta belum terlibat dalam usaha formal, sebanyak 26,66 persen peserta terlibat usaha informal, dan 13,33 persen peserta terlibat dalam usaha formal.

Tabel 2.7 Pengetahuan tentang pemanfaatan lingkungan

\begin{tabular}{|c|c|c|}
\hline $\begin{array}{l}\text { Pengetahuan tentang } \\
\text { pemanfaatan lingkungan }\end{array}$ & Jumlah & Persentase \\
\hline 1. Belum tahu & 2 & 13,33 \\
\hline $\begin{array}{l}\text { 2. Hanya mendengar tetapi belum tahu apa } \\
\text { yang bisa dimanfaatkan }\end{array}$ & 9 & 60,00 \\
\hline 3. Sudah tahu tetapi tidak memanfaatkannya & 1 & 6,66 \\
\hline $\begin{array}{l}\text { 4. Sudah mengetahui dan sudah } \\
\text { memanfaatkan dalam kegiatan ekonomi }\end{array}$ & 3 & 20,00 \\
\hline
\end{tabular}


Berdasarkan pengetahuan tentang pemanfaatan lingkungan, terdapat 60,00 persen dari seluruh peserta pelatihan lilin aromaterapi hanya mendengarkan dan belum mengetahui hal yang bisa dimanfaatkan dari lingkungan alam sekitar mereka untuk dijadikan sesuatu yang lebih bernilai guna. Sebanyak 20,00 persen belum tahu tentang pemanfaatan lingkungan, tetapi sudah mengetahui dan memanfaatkan hal yang ada di sekitar tempat tinggal mereka untuk kegiatan ekonomi. Sisanya, sebesar 6,66 persen dari seluruh peserta sudah mengetahui, tetapi tidak memanfaatkan lingkungan sekitar tempat tinggal mereka.

\begin{tabular}{|c|c|c|}
\hline $\begin{array}{l}\begin{array}{l}\text { Pengetahuan } \\
\text { aromaterapi }\end{array} \\
\text { tentang }\end{array}$ & Jumlah & Persentase \\
\hline 1. Belum tahu & 2 & 13,33 \\
\hline 2. Hanya mendengar tetapi belum tahu seperti apa & 2 & 13,33 \\
\hline $\begin{array}{l}\text { 3. Sudah tahu tetapi tidak mengetahui cara } \\
\text { pembuatannya }\end{array}$ & 6 & 40,00 \\
\hline $\begin{array}{l}\text { 4. Sudah mengetahui cara pembuatan lilin } \\
\text { aromaterapi }\end{array}$ & 5 & 33,30 \\
\hline
\end{tabular}

Berdasarkan pengetahuan tentang lilin aromaterapi, terdapat 40,00 persen menyatakan bahwa mereka sudah tahu, tetapi tidak mengetahui cara pembuatan lilin aromaterapi. Sebanyak 33,3 persen dari seluruh peserta sudah mengetahui cara pembuatan lilin aromaterapi. Sebanyak 13,3 persen peserta belum tahu cara pembuatan dan hanya mendengar, tetapi belum mengetahui yang dimaksud dengan lilin aromaterapi tesebut.

Tabel 2.9 Komposisi peserta berdasarkan motivasi mengikuti pelatihan

\begin{tabular}{clcc}
\hline \hline Motivasi & Jumlah & Persentase \\
\hline 1. & Hanya ingin tahu & 3 & 20,00 \\
2. & Ingin mempraktekkan & - & 66,66 \\
3. $\quad \begin{array}{l}\text { Ingin mempraktekkan dan } \\
\text { menjualnya }\end{array}$ & 10 & 6,66 \\
4. $\quad \begin{array}{l}\text { Ingin mempraktekkan dan } \\
\text { memproduksi masal }\end{array}$ & 1 & 6,66 \\
$\quad \begin{array}{l}\text { Ingin mempraktekkan dan nantinya } \\
\text { mempekerjakan orang }\end{array}$ & 1 & \\
& & & \\
\end{tabular}

Dilihat dari komposisi peserta berdasarkan motivasi mereka mengikuti pelatihan lilin aromaterapi, terdapat 66,66 persen dari seluruh peserta termotivasi karena mereka ingin mempraktikkan dan nantinya akan dijual untuk menabah income keluarga. Sebanyak 20,00 persen peserta hanya ingin mempraktikkan sendiri dalam membuat lilin aromaterapi agar bisa diproduksi untuk diri sendiri ataupun untuk keluarga mereka. Sebanyak 6.66 persen peserta ingin mempraktikkan dan nantinya akan mempekerjakan orang untuk memproduksinya serta nantinya ingin mempraktikkannya lalu diproduksi massal. 
Tabel 2.10 Persepsi peserta tentang manfaat pelatihan lilin aromaterapi

\begin{tabular}{lcc}
\hline \hline Persepsi Peserta & Jumlah & Persentase \\
\hline Bermanfaat & 15 & 100 \\
Tidak Bermanfaat & 0 & 0 \\
\hline
\end{tabular}

Berdasarkan persepsi peserta tentang manfaat pelatihan lilin aromaterapi, seluruh peserta pelatihan berpendapat bahwa pelatihan tersebut bermanfaat bagi mereka. Mereka beranggapan bahwa pelatihan tersebut dapat menambah pengetahuan dan keterampilan mereka karena mereka belum pernah mendapatkan pelatihan pembuatan lilin aromaterapi sebelumnya.

Pembuatan lilin aromaterapi adalah pembuatan keterampilan yang sangat mudah untuk dilakukan dan memberikan hasil yang bernilai mengguntungkan. Ketersediaan bahan alami yang ada di lingkungan alam sekitar masyarakat digunakan sebagai bahan baku utama lilin aromaterapi. Hal ini membuat warga semakin tertarik membuat lilin aromaterapi. Bahan baku utama pembuatan lilin aromaterapi adalah limbah minyak jelantah yang dikolaborasikan dengan daun jeruk dan sereh. Oleh karena itu, sebelum melaksanakan pelatihan, tim pelaksana pemberdayaan masyarakat melakukan observasi terlebih dahulu ke lokasi, yaitu di Dusun Sorowajan, Pedukuhan Glugo, Desa Pangungharjo, Kecamatan Sewon untuk mengidentifikasi jenis bahan minyak jelantah yang dapat dijadikan bahan utama dalam pembuatan lilin aromaterapi. Setelah bahan baku dan semua peralatan pembuatan lilin aromaterapi disiapkan, pelatihan dilakukan di Dusun Sorowajan, Pedukuhan Glugo, Desa Pangungharjo, Kecamatan Sewon, 26 Juli 2020 pukul 08.00-12.00 WIB.

Adapun pelaksanaan pelatihan pembuatan lilin aromaterapi di Dukuh IV Dusun Sorowajan, Pedukuhan Glugo, Desa Pangungharjo, Kecamatan Sewon, Kabupaten Bantul adalah peserta diminta menyiapkan alat dan bahan yang dibutuhkan untuk membuat lilin aromaterapi. Selanjutnya, masing-masing peserta membawa limbah minyak jelantah dari rumah untuk dijadikan bahan utama dalam pembuatan lilin aromaterapi.

Sebelum melakukan praktik pembuatan lilin aromaterapi, terlebih dulu peserta menyaksikan video cara membuat lilin aromaterapi yang telah di-upload di youtube dan dikunjungi oleh lebih dari 100 pengguna youtube. Dengan menyaksikan cara pembuatan lilin aromaterapi terlebih dahulu, diharapkan dapat mempermudah peserta untuk mepraktikkan sendiri tentunya dengan didampingi instruktur. Pada saat menyaksikan video tersebut, instruktur memberikan pengantar untuk menjelaskan secara detail cara pembuatan lilin aromaterapi melalui daring.

\section{A. Tutorial Pembuatan Lilin Aromaterapi}

Tanpa disadari, kata aromaterapi telah menjadi bagian dalam kehidupan manusia modern sejalan dengan komitmen back to nature. Walaupun demikian, banyak orang di Indonesia belum memahami benar makna dan manfaat aromaterapi. Aromaterapi dikonotasikan lebih sebagai pengharum ruangan dan tubuh untuk menghasilkan efek tenang dan rileks atau membangkitkan suasana romantis. Padahal, sesungguhnya, manfaat aromaterapi jauh lebih luas dan dahsyat. Sejak zaman sebelum Masehi, aromaterapi telah digunakan dalam perawatan kesehatan di samping perawatan kecantikan. Kini, memasuki abad ke-21, aromaterapi semakin diyakini, bahkan diterapkan, sebagai perawatan murni alami untuk memulihkan kesehatan dan kesejahteraan tubuh. Hal ini merupakan suatu perawatan yang aman, tidak menimbulkan efek yang merugikan sebagaimana yang sering timbul saat perawatan atau pengobatan dengan menggunakan zat kimiawi (Primadiati, 2002). Untuk membuat produk lilin aromaterapi, mulamula peserta harus mempersiapkan terlebih dahulu berbagai macam alat dan bahan yang dibutuhkan untuk menunjang kegiatan pelatihan (Rizka, 2014). Peralatan dan bahan-bahan yang dimaksud di antaranya berupa 
1. Parafin.

Membeli parafin sesuai kebutuhan saja, yaitu 100-250 gram. Jumlahnya sebanyak 250 gram sudah bisa menghasilkan lilin tiga gelas kaca.

\section{Bibit Parfum Aromaterapi}

Kegunaan bibit parfum ini kegunaannya untuk menghilangkan bau pada minyak jelantahnya. Bibit parfum ini dijual dalam mililiter. Satu mililiter harganya berbedabeda. Saya membeli green tea dengan harga berkisar Rp4.000/ ml. Bibit parfum ini pakai sedikit sudah wangi. Takaran menggunakan parfum bisa diperkirakan. Kalau dirasa sudah cukup, hentikan.

\section{Sumbu lilin / Tali Kenur / Kapas}

Supaya sumbu lilin bisa berdiri tegak, dibutuhkan sumbu lilin khusus. Jika darurat, bisa menggunakan tali kenur. Tali ini gunanya sebagai sumbu lilinnya. Kalau tidak ada bisa gunakan kapas kecantikan. Tali kenur bisa dibeli ditoko bangunan dengan harga Rp2.000,00.

\section{Minyak Jelantah}

Kami memakai minyak jelantah sisa menggoreng daging / nondaging jadi satu. Kalau kotor disaring dulu. Akan tetapi, kotorannya biasanya mengendap, jadi tidak perlu disaring. Bau minyak jelantah bisa ditutupi dengan parfum dan hasilnya tidak akan muncul bau minyak jelantah sama sekali.

\section{Gelas Kaca / Toples Kaca Bekas Selai}

Gelas kaca digunakan untuk wadah lilinnya nanti. Jangan gunakan plastik karena nanti bisa meleleh saat dibakar. Bisa menggunakan kaleng alumunium, tetapi harus hati-hati saat lilin menyala. Wadah dari kaleng cenderung lebih panas karena aluminium penghantar panas / isolator yang lebih cepat daripada kaca.

\section{Timbangan Digital}

Kegunaan timbangan digital adalah untuk menimbang bahan supaya akurat. Gunakan setting untuk air saat menimbang minyak jelantah dan gunakan setting padat saat menimbang parafin karena bahan-bahan yang kita timbang berbeda, yaitu cair dan padat.

\section{Panci / Wajan dan Spatula.}

Panci digunakan khusus untuk mengolah minyak jelantah. Jangan digunakan untuk memasak.

\section{Parutan}

Parutan digunakan untuk memarut bahan lilin, yaitu parafin. 


\section{Pewarna Makanan Food Grade (opsional).}

Saat praktik membuat lilin pertama kali, kami tidak menggunakan pewarna makanan. Akan tetapi, pernah melihat percobaan pembuatan lilin aromaterapi lain yang menggunakan pewarna makanan dan hasilnya lebih menarik.

\section{Cara Membuat Lilin Aromaterapi}

1. Timbang terlebih dahulu bahan-bahannya, baik parafin maupun minyak jelantah. Timbang dengan perbandingan 1: 1. Misalnya, minyak jelantah 100 gram, parafin 100 gram.

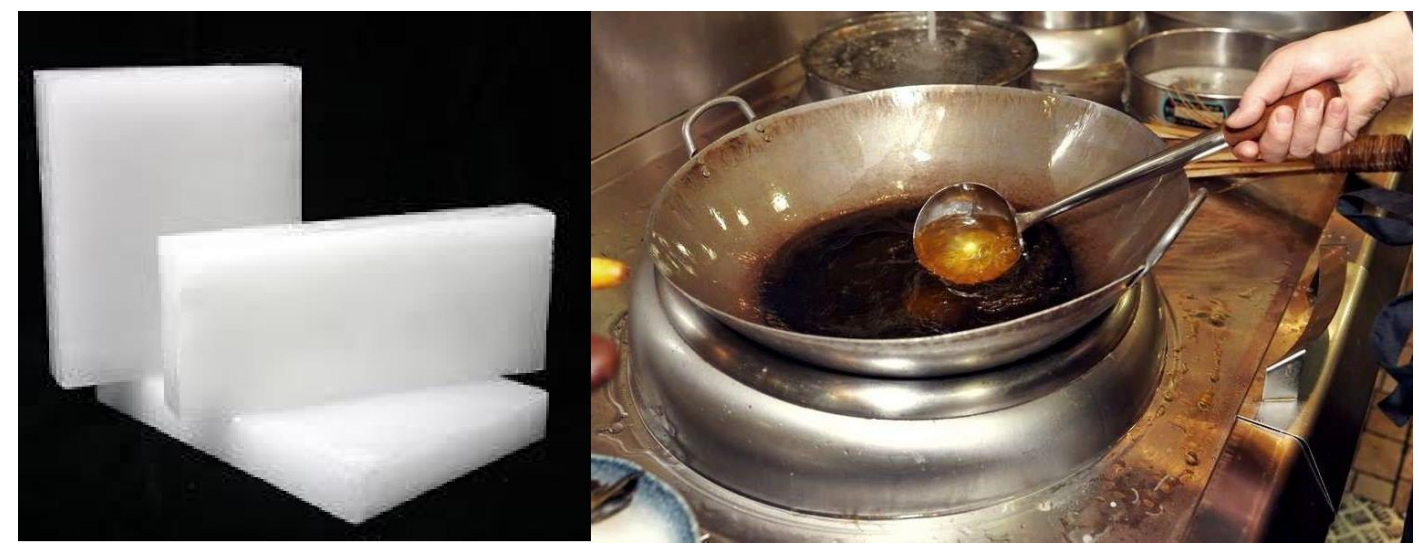

Gambar 1.1 Menakar bahan dasar lilin aromaterapi

2. Parut dulu parafinnya / potong dulu menjadi bagian yang kecil-kecil karena parafin yang bentuknya balok agak keras. Tujuannya adalah supaya parafin cepat meleleh.

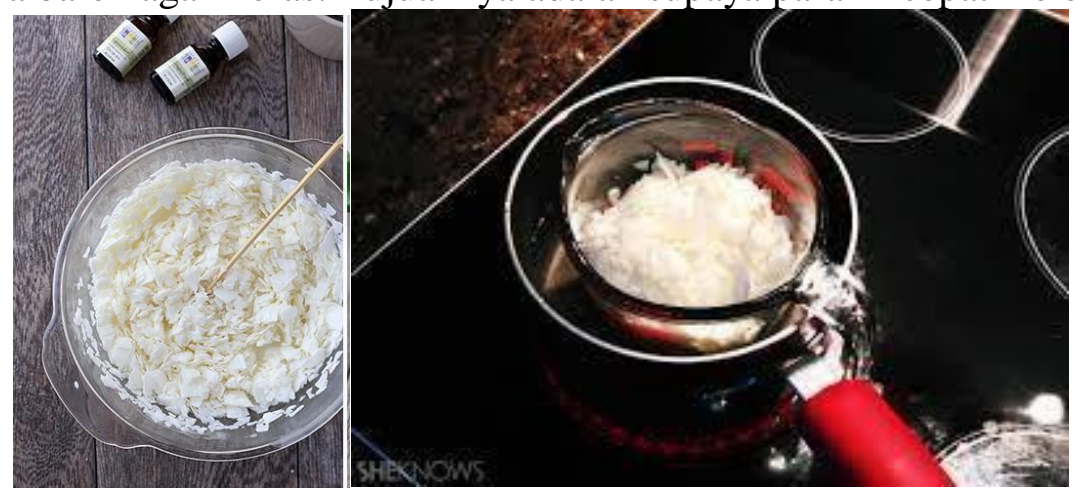

Gambar 1.2 Proses memarut dan mencairkan parafin

3. Nyalakan kompor gas dan panaskan minyak jelantah menggunakan api kecil. Jika dirasa sudah cukup panas, masukkan parafinnya lalu aduk-aduk hingga tercampur dengan baik. Ini mirip saat kita memanaskan mentega/margarin. Jika sudah encer semua, masukkan bibit parfumnya. Cukup masukkan seperlunya dengan mencium baunya. Jika dirasa cukup, hentikan pemberian parfum. Aduk-aduk supaya tercampur rata antara parfum. minyak jelantah, dan parafinnya. 


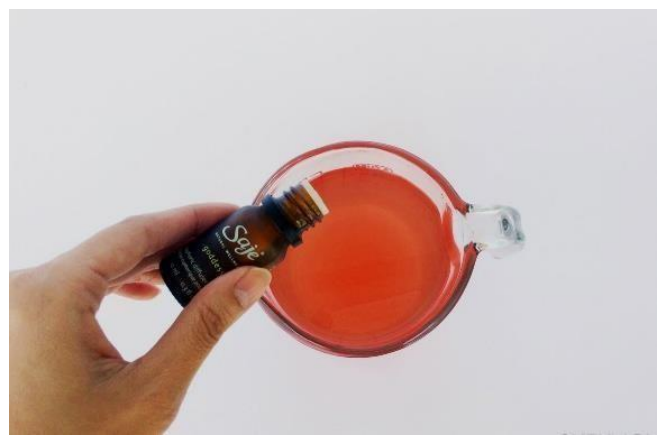

Gambar 1.3 Memasukkan bibit parfum atau aromaterapi

4. Masukkan/rendam sumbu ke dalam minyak jelantah yang sudah dimasak dengan parafin tadi. Tujuannya adalah supaya sumbu menyerap minyak. Karena pengalaman kami, jika tidak direndam ke dalam minyak terlebih dahulu, tali/kapas terbakar habis saat dinyalakan lilinnya dengan menggunakan korek. Berbeda jika diberi minyak terlebih dahulu. Jika sudah, masukkan sumbu ke dalam gelas kaca. Sumbu yang terkena minyak jelantah yang sudah tercampur parafin nanti cepat mengeras. Jadi, sumbunya nanti jadinya kaku. Ini justru mempermudah meletakkan sumbu di gelasnya nanti.

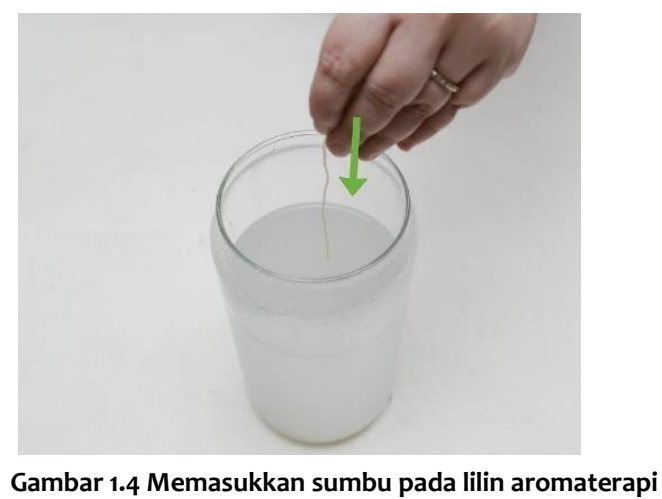

5. Masukkan sumbu di tengah-tengah gelas kaca, lalu tuangkan minyak jelantah. Tuangkan hingga sebatas dua $\mathrm{cm}$ dari ujung tali sumbunya ya. Jangan dituang hingga sumbunya tenggelam. Nanti kesulitan saat mau membakar sumbunya. Tunggu hingga benar-benar dingin. Kurang lebih dua jam pada suhu ruang, atau kalau mau lebih cepat dingin, masukkan ke lemari es. Akan tetapi, harus hati-hati, tunggu sampai lilinnya benar-benar dingin lalu masukkan ke lemari es.

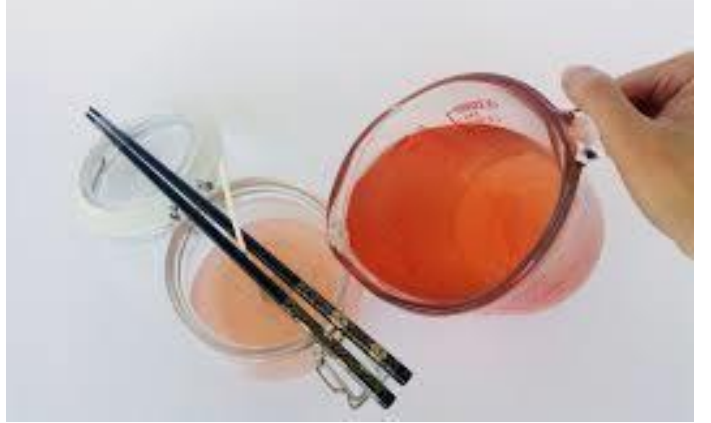

Gambar 1.4 Lilin telah mengeras dan tegakkan sumbu dengan penjepit bisa gunakan sumpit (kayu)

6. Lilin siap digunakan. Berdasarkan pengalaman, perlu beberapa kali percobaan hingga akhirnya menyala. Biasanya, 2-3 kali dipancing dengan api kemudian baru 
menyala.

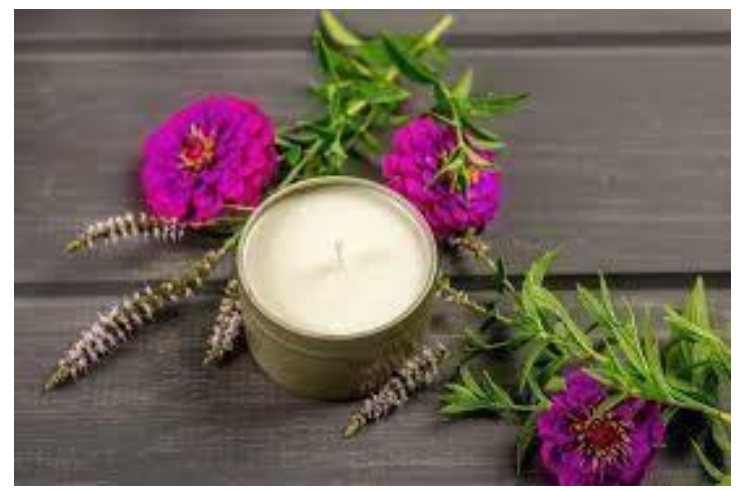

Gambar 1.5 Lilin siap digunakan

\section{B. Pelatihan Pembuatan Lilin Aromaterapi}

Pada pelatihan ini materi, bahan dan peralatan sudah dipersiapkan oleh tim pengusul. Kelompok Dasawisma diundang untuk mengikuti pelatihan pembuatan lilin aromaterapi. Lilin aromaterapi adalah lilin khusus yang terbuat dari minyak esensial dengan aroma yang begitu menenangkan dan menyenangkan. Lilin aromaterapi juga sudah digunakan sejak beberapa abad terakhir untuk merelaksasikan suasana. Dalam hal ini, dalam PKM kali ini, lilin dibuat dari bahan dasar minyak jelantah dan parafin serta aroma dari bahan alami tumbuh-tumbuhan. Dalam pelatihan pembuatan lilin aromaterapi, masing-masing peserta dibagikan alat dan bahan yang telah disiapkan sebelumnya di dalam nampan plastik. Alat dan bahan tersebut meliputi berbagai parafin, daun jeruk, sereh, tambahan aroma, dan wadah lilin yang telah disediakan dan dibawa oleh peserta.

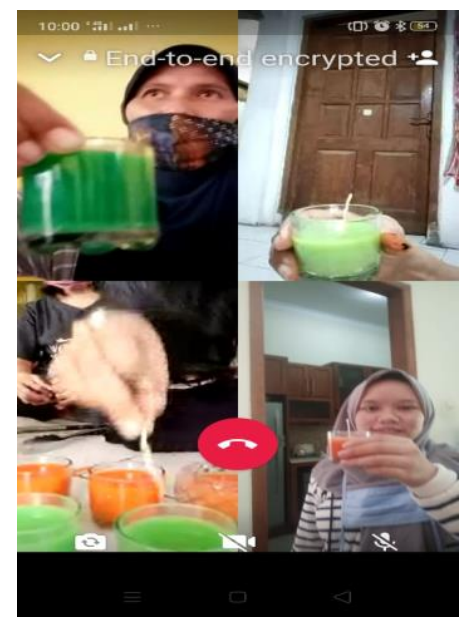

Gambar 2.1 Proses pelatihan pembuatan lilin aromaterapi secara daring

Dengan beberapa asisten, para peserta mulai melakukan langkah demi langkah pembuatan lilin aromaterapi. Apabila ada kesulitan atau pertanyaan, peserta memberi tahu asisten atau instruktur untuk menjelaskan caranya. Langkah awal yang harus dilakukan peserta adalah panaskan minyak jelantah, lalu masukkan parafin dicampur hingga merata dengan minyak jelantah. Selanjutnya masukkan crayon dan diaduk, lalu masukkan aromaterapi, kemudian tuangkan adonan lilin pada wadah gelas yang sudah disiapkan, dan terakhir tancapkan sumbu lilin kemudian diamkan lilin hingga mengeras. Sumbu lilin yang digunakan 
adalah sumbu lilin yang khusus.

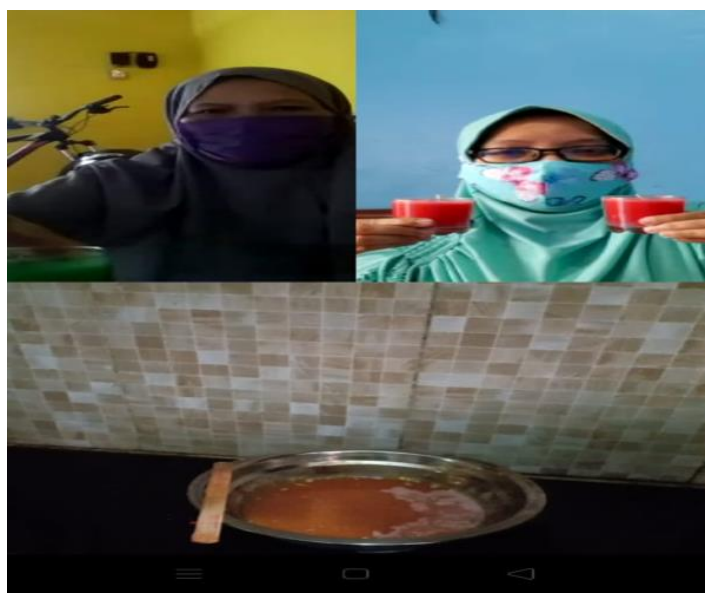

Gambar 2.2 Proses pembuatan lilin aromaterapi

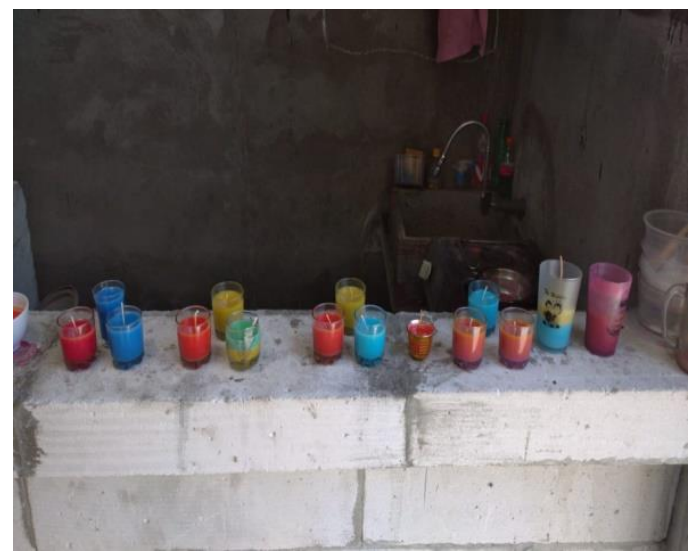

Gambar 2.3 Produk pembuatan lilin aromaterapi

\section{G. Pembuatan Video Tutorial dan Pelatihan Pembuatan Lilin Aromaterapi}

Program Kemitraan Masyarakat (PKM) ini juga bertujuan untuk meningkatkan kapasitas masyarakat, khusunya di Desa Panggungharjo dan masyarakat luas pada umumnya, dalam membuat produk lilin aromaterapi agar dapat meningkatkan pendapatan melalui ekonomi kreatif ini. Salah satu kegiatan pemberdayaan masyarakat ini adalah membuat video tentang tata cara pembuatan lilin aromaterapi dengan memanfaatkan bahan alami yang ada di sekitar Dusun Sorowojan. Hasil dari kegiatan ini adalah terwujudnya pembelajaran online tentang pembuatan lilin aromaterapi oleh ibi-ibu Dasawisma Lili. Video ini ditujukan agar masyarakat dapat membuat produk lilin aromaterapi dengan mudah dengan bahan sederhana sehingga mereka dapat memproduksi sendiri setelah menyaksikan video dan mempraktikkannya melalui pelatihan.

Sebagaimana dikatakan Nurfathiyah dkk. (2011), video merupakan salah satu media elektronik yang mampu menggabungkan teknologi audio dan visual secara bersama sehingga menghasilkan suatu tayangan yang dinamis dan menarik. Video ini tidak hanya diperuntukkan bagi warga masyarakat Dusun Sorowojan, tetapi juga bisa dimanfaatkan oleh masyarakat luas pengguna media sosial. Oleh karena itu, PKM ini juga membuat video tutorial teknik pembuatan lilin aromaterapi agar kelompok masyarakat yang mengikuti pelatihan bisa lebih paham dan memproduksinya sendiri dan masyarakat luas dapat mencoba untuk membuat lilin aromaterapi, baik untuk kebutuhan sendiri maupun untuk dijual, guna meningkatkan pendapatan mereka. 
Video ini nantinya akan di-upload di media sosial agar bisa dilihat oleh masyarakat luas. Video cara pembuatan lilin aromaterapi ini bisa dibuka di website berikut https://youtu.be/02htwTetoPU

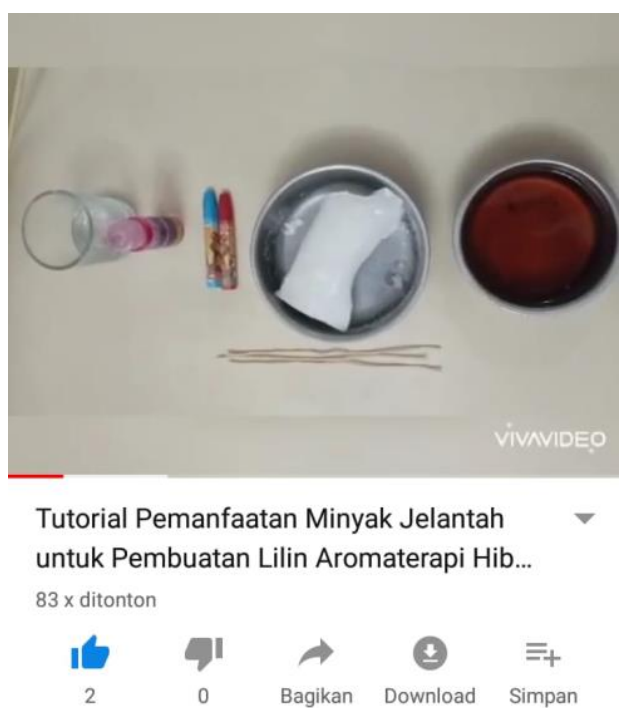

Gambar 3.1 Video tutorial pembuatan lilin aromaterapi
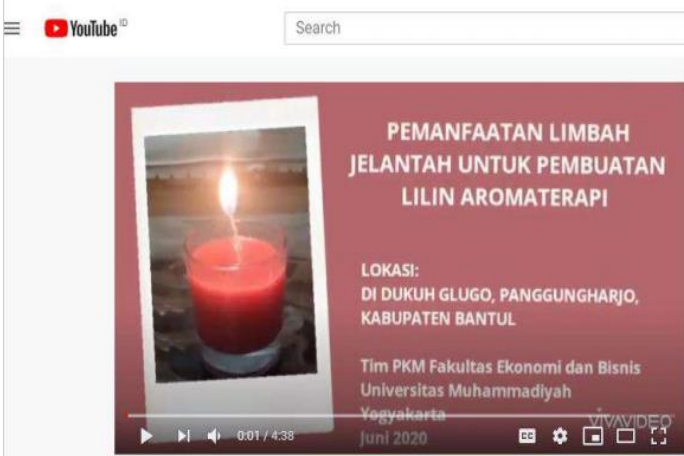

PKM Ekonomi Kreatif: Lilin Aromaterapi dari Limbah Minyak Jelantah - Dyah Titis Kusuma Wardani

No views · Jul 28, 2020

I1. 0 \% O 0 SHARE F SAVE

Gambar 3.2 Video kegiatan pelatihan pembuatan lilin aromaterapi

Adanya kegiatan pemberdayaan masyarakat berupa pelatihan lilin aromaterapi tersebut dapat meningkatkan kapasitas masyarakat, terutama ibu-ibu Dasawisma Lili, Dusun Sorowajan, Pedukuhan Glugo, Desa Pangungharjo, Kecamatan Sewon, Kabupaten Bantul dalam mendapatkan penghasilan.

\section{Tindak lanjut Pemasaran Online Produk Lilin Aromaterapi}

Untuk keberlanjutan pelatihan lilin aromaterapi dan untuk mendukung tercapainya tujuan pelatihan lilin aromaterapi, yaitu meningkatkan pendapatan masyarakat melalui ekonomi kreatif, tim PKM UMY juga menindaklanjuti dengan kegiatan pemasaran online agar produk yang dihasilkan masyarakat sebagai output dari pelatihan dapat dijual sehingga memberi tambahan pendapatan masyarakat. Ide pemasaran secara online juga dijalankan dalam rangkaian pelatihan pembuatan lilin aromaterapi, dalam bentuk sesi foto produk lilin aromaterapi. Dengan demikian, penyajiannya menjadi menarik dan layak jual. Dari semua pelatihan ini, masyarakat diharapkan tidak hanya bisa menghasilkan barang yang bernilai jual tinggi, tetapi juga bisa 
memasarkannya sehingga memperoleh pendapatan.

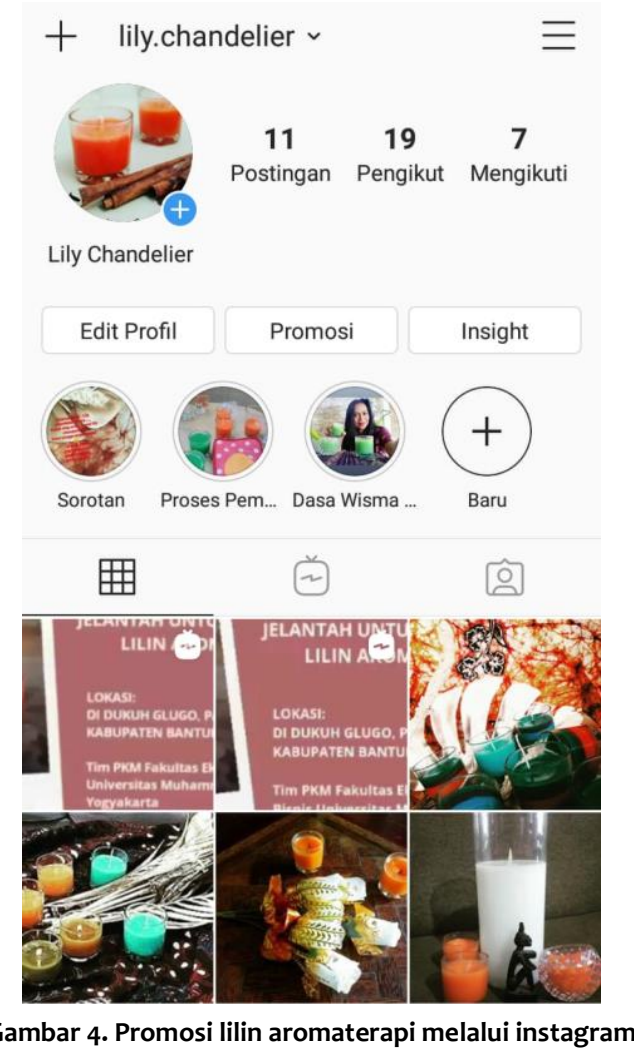

\section{Simpulan}

Belum adanya pemanfaatan potensi alam di lingkungan sekitar Dusun Sorowajan mendorong diadakannya pelatihan pembuatan lilin aromaterapi. Pelatihan ini dapat mengembangkan keterampilan kelompok ibu-ibu Dasawisma Lili Dusun Sorowajan dalam memanfaatkan potensi alam desanya. Hal ini tentunya memberi manfaat, baik dari segi ekonomi maupun sosial. Dengan meningkatnya keterampilan ibu-ibu Dasawisma Lili, kegiatan ekonomi lokal secara tidak langsung meningkat sehingga menambah kesejahteraan masyarakat di lingkungan sekitar.

Masyarakat Dasawisma Lili Dusun Sorowajan memiliki potensi alam yang bernilai,yakni sisa minyak jelantah. Minyak jelantah ini digunakan sebagai bahan pembuatan lilin aromaterapi. Lilin aroma terapi ini merupakan produk yang layak jual. Dengan adanya pembuatan lilin aroma terapi ini, masyarakat bisa menghasilkan income secara mandiri untuk menambah pemasukan keluarga. Hasil dari kegiatan pemberdayaan masyarakat ini adalah meningkatnya kapasitas masyarakat dalam memproduksi lilin aromaterapi.

Pelatihan lilin aromaterapi ini juga didukung dengan pembuatan video cara membuat lilin aromaterapi. Hasil dari pembuatan video tersebut adalah terwujudnya pembelajaran online tentang pembuatan lilin aromaterapi. Dengan video ini, masyarakat dapat membuat produk lilin aromaterapi sendiri dengan mudah dan dengan bahan sederhana sehingga mereka dapat memproduksi sendiri setelah menyaksikan video dan mempraktikkannya di rumah masingmasing atau bersama kelompoknya.

Selain diperuntukkan bagi warga masyarakat Dasawisma Lili, Dusun Sorowajan, video ini juga bisa dimanfaatkan oleh masyarakat luas pengguna media sosial dengan mengakses youtube yang berjudul "PKM Ekonomi Kreatif. Lilin aromaterapi dari Limbah Minyak 
Jelantah". Diharapkan dengan adanya program ini, diharapkan masyarakat luas, khususnya masyarakat Dasawisma Lili, Dusun Sorowajan, dapat membuat lilin aromaterapi dan memproduksinya dalam jumlah besar sehingga dapat meningkatkan kesejahteraan rumah tangganya. Di samping itu, dengan semakin meningkatnya kapasitas masyarakat dalam membuat lilin aromaterapi, dapat dikembangkan metode lain yang juga layak dijual sehingga semakin meningkatkan kesejahteraan masyarakat.

\section{Ucapan Terima Kasih}

Kami selaku tim pengabdian, Dyah Titis Kusuma Wardani, Endah Saptutyningsih, dan Suci Alpika Fitri mengucapkan terima kasih kepada pihak LP3M Universitas Muhammadiyah Yogyakarta atas dukungan hibah pengabdian melalui Surat Penetapan Kepala LP3M No. 031/PEN-LP3M/I/2020 yang telah diberikan lengkap dengan berbagai fasilitas dan kemudahannya untuk proses diseminasi melalui Webinar Abdimas UMY 2020, publikasi pada jurnal ilmiah, serta rilis berita di media massa. Terima kasih kepada Harian Jogja yang telah meliput kegiatan pengabdian kami. Tidak lupa kami ucapkan terima kasih kepada instruktur kami, Ibu Esty Setyaningrum, M.Si., atas arahan dan instruksi yang sangat rapi dan terstruktur hingga produk lilin aromaterapi ini dapat kami nikmati. Terima kasih kami ucapkan kepada Ketua Dasawisma Lili, Ibu Dra.Veronica Dwihening, atas kesediaan komunitas Dasawisma Lili menjadi target program pengabdian kepada masyarakat. Semoga produk lilin aromaterapi bermanfaat sebagai salah satu ekonomi kreatif penggerak perekonomian masyarakat khususnya di Dusun Sorowajan.

\section{Daftar Pustaka}

Bennet, H. (1963). Industrial Waxes. Vol. 1. Natural and Synthetic Waxes. Chemical Publishing Company. Inc., New York.

Desa Panggungharjo. (2017). Data Monografi Desa Paggungharjo Kecamatan Sewon, Kabupaten Bantul, DIY.

Diego A.M., Jones, N.A., Field T., Hernandez-Reif M, Schanberg, S., Kuhn, C., McAdam, V., Galamaga, R., Galamaga, M. (1998). Arometherapy Positively Affects Mood, EEG Pattern of Alertness and Math Computations. International Journal of Neuroscience. Vol. 96, pp. 217-224.

Fadhil, S. (2007). Pengelolaan Sumberdaya Alam dan Lingkungan Berbasis Pengetahuan dan Kearifan Lokal (Local Wisdom) di Kalimantan. Jurnal Borneo Administrator. Vol. 3, No. 1, pp. 72-92.

Faidliyah. (2017). Pembuatan Lilin Aromaterapi Berbasis Bahan Alami. Jurnal Prodi Teknik Kimia Institut Teknologi Malang. Diakses dari http://library.binus.ac.id/eColls/eThesisdoc/Bab2/2012-2-01732-DS\%20Bab2001.pdf., tanggal 13

Maret 2019.

Grainge, M. dan Ahmed, S. (1987). Handbook of Plants with Pest Control Properties. WilleyInterscience Publication, New York. pp. 470.

https://books.google.co.id/books?isbn=97 92246010 https://id.wikipedia.org/wiki/Aromaterapi. Khamidinal, M. Si, Teknik Laboratorium Kimia, Penerbit: Pustaka Pelajar, Oktober, 
International Labour Organization. (2017). Pelatihan Keterampilan Pedesaan: Manual Generik Pelatihan untuk Pemberdayaan Ekonomi Pedesaan (TREE).

Megawati dan Murniyawati, F. (2015). Microwave Assisted Hydrodistillation untuk Ekstraksi Minyak Atsiri dari Kulit Jeruk Bali Sebagai Lilin Aromaterapi. Jurnal Bahan Alam Terbarukan. Vol. 4, No. 1, pp. 14- 20.

Murdani, R. (2014). Keefektivan Daya Bunuh Ekstrak Daun Jeruk Nipis (Citrus aurantifolia Swingle) Terhadap Kematian Larva Nyamuk Aedes aegypti Instar III. Surakarta: Univesitas Muhammadiyah Surakarta Press.

Murhananto dan Aryasatyani, R. (2000). Membuat dan Mendekorasi Lilin. Puspa Swara, Jakarta.

Nurfathiyah, P., Mara, A., Siata, R., \& Farida, A. (2011). Pemanfaatan Video sebagai Media Penyebaran Inovasi Pertanian. Jurnal Pengabdian Kepada Masyarakat, Vol. 52, pp. 3036.

Prabandari, S. dan Febriyanti, R. (2017). Formulasi dan Aktivitas Kombinasi Minyak Jeruk dan Minyak Sereh Pada Sediaan Lilin Aromaterapi. Parapemikir: Jurnal Ilmiah Farmasi, Vol. 6, No.1, pp. 124-126.

Primadiati, R. (2002). Aromaterapi: Perawatan Alami Untuk Sehat dan Cantik. PT. Gramedia Pustaka Utama, Jakarta.

Rahman, H., Adi, H. R., Yuliani, D dan Rinah (2019). Pelatihan Pembuatan Lilin Aromaterapi di Pedukuhan Jangkang Lor, Sentolo, Kulonprogo. Jurnal Pemberdayaan: Publikasi Hasil Pemberdayaan kepada Masyarakat, Vol. 3, No. 2. pp. 237-240.

Rizka, L. (2014). Pengertian Lilin Aromaterapi. (Online). Diakses pada tanggal 29 Agustus 2017.

Sahi, I, Molamahu, A.A., Noho, A., Abas, R. N. R., Malingkonor, A.dan Bempa, S. H. (2017). Esterifikasi Minyak Goreng Bekas Pada Pembuatan Lilin Aromaterapi. Pengantar Rekayasa \& Desain. Jurusan Kimia, FMIPA, Universitas Negeri Gorontalo (UNG), Kota Gorontalo.

Shofi, M (2019). Pemberdayaan Anggota PKK Melalui Pembuatan Lilin Aromaterapi. Journal of Community Engagement and Employment. Vol. 01. No. 01, pp 40-46.

Tirtasari, N. dan Aji, H.S. (2018). Lilin Aromaterapi dari Ekstrak Tumbuh-tumbuhan di sekitar Laboratorium Biologi Unnes. Rekayasa Vol. 16 No. 1, pp. 23-26. 